\title{
Measurement of antibiotic consumption: A practical guide to the use of the Anatomical Therapeutic Chemical classification and Defined Daily Dose system methodology in Canada
}

\author{
James M Hutchinson MD FRCPC ${ }^{1}$, David M Patrick MD MHSc FRCPC ${ }^{2}$, Fawziah Marra PharmD ${ }^{2}$, Helen Ng BSc ${ }^{2}$, \\ William R Bowie MD FRCPC ${ }^{2}$, Laurie Heule BSc(Pharm) ${ }^{3}$, Mark Muscat MD MSc ${ }^{4}$, Dominique L Monnet PharmD PhD ${ }^{4}$
}

\begin{abstract}
JM Hutchinson, DM Patrick, F Marra, et al. Measurement of antibiotic consumption: A practical guide to the use of the Anatomical Therapeutic Chemical classification and Defined Daily Dose system methodology in Canada. Can J Infect Dis 2004;15(1):29-35.

Despite the global public health importance of resistance of microorganisms to the effects of antibiotics, and the direct relationship of consumption to resistance, little information is available concerning levels of consumption in Canadian hospitals and out-patient settings. The present paper provides practical advice on the use of administrative pharmacy data to address this need. Focus is made on the use of the Anatomical Therapeutic Chemical classification and Defined Daily Dose system. Examples of consumption data from Canadian community and hospital settings, with comparisons to international data, are used to incite interest and to propose uses of this information. It is hoped that all persons responsible for policy decisions regarding licensing, reimbursement, prescribing guidelines, formulary controls or any other structure pertaining to antimicrobial use become conversant with the concepts of population antibiotic consumption and that this paper provides them with the impetus and direction to begin accurately measuring and comparing antibiotic use in their jurisdictions.
\end{abstract}

Key Words: Antibacterial agents; Drug utilization; Pharmacoepidemiology
Mesure de la consommation d'antibiotiques : guide pratique concernant l'utilisation du Système de classification anatomique thérapeutique chimique et du système de posologie quotidienne recommandée au Canada
WHY MEASURE ANTIBIOTIC CONSUMPTION? Antibiotic resistance is a global public health problem. While many reports have described serious misuse of antibiotics and the need for rational antibiotic prescribing practices (1-5), there are surprisingly few published descriptions or comparisons of antibiotic consumption (6-12). This lack of information has hindered rational discussions about desirable levels of consumption - the ultimate objective of all concerned with this issue. Many factors must be considered in attempting to define best levels of consumption, including local disease prevalence, susceptibility patterns, antibiotic prescribing practices and philosophy of their use. Comparisons with other populations, especially similar ones, help to give context. A reasonable question posed by an Argentinean researcher
Malgré l'importance, en santé publique, de la résistance des microorganismes aux effets des antibiotiques et le lien direct entre la consommation et cette résistance, il existe peu de données sur le degré de consommation des antibiotiques dans les hôpitaux et les services de consultations externes au Canada. Le présent article donne des conseils pratiques sur l'utilisation de données administratives en pharmacie à cet égard. Il sera question en particulier du Système de classification anatomique thérapeutique chimique et du système de posologie quotidienne recommandée ( DDD»). Nous y présentons des exemples de données sur la consommation de médicaments en milieu hospitalier et dans la communauté au Canada par rapport à des données internationales pour susciter l'intérêt et proposer des utilisations possibles de l'information existante. Aussi espérons-nous que toutes les personnes responsables de prises de décision en matière de politique concernant l'autorisation de mise sur le marché, le remboursement, les lignes directrices sur les pratiques de prescription, le contrôle des médicaments inscrits au formulaire ou toute autre structure relative à l'utilisation des antimicrobiens connaissent les concepts de consommation d'antibiotiques dans la population. Nous espérons également que cet article leur donnera l'élan pour commencer à mesurer précisément et à comparer l'utilisation des antibiotiques sur leur territoire et les orientera dans leur démarche.

${ }^{1}$ Memorial University of Newfoundland, St John's, Newfoundland; ${ }^{2}$ University of British Columbia, Vancouver, British Columbia; ${ }^{3}$ Calgary Health Authority, Calgary, Alberta; ${ }^{4}$ Statens Serum Institut, Copenhagen, Denmark

Correspondence and reprints: Dr Jim Hutchinson, Department of Microbiology, Health Sciences Centre, 300 Prince Philip Drive, St John's,

Newfoundland A1B 3V6. Telephone 709-777-7654, fax 709-777-7655, e-mail jim.hutchinson@hccsj.nl.ca

Received for publication September 11, 2003. Accepted November 9, 2003 
TABLE 1

Classification of amoxicillin of the Anatomical Therapeutic Chemical (ATC) classification system

\begin{tabular}{lll}
\hline ATC classification & ATC category & Description \\
\hline J & General anti-infectives for systemic use & $1^{\text {st }}$ level, anatomical main group \\
J01 & Antibacterials for systemic use & $2^{\text {nd }}$ level, therapeutic main group \\
J01C & Beta-lactam antibacterials, penicillins & $3^{\text {rd }}$ level, therapeutic/pharmacological subgroup \\
J01C A & Penicillins with extended spectrum & $4^{\text {th }}$ level, chemical/therapeutic/pharmacological subgroup \\
J01C A04 & Amoxicillin & $5^{\text {th }}$ level, subgroup for chemical substance
\end{tabular}

TABLE 2

Examples of Defined Daily Doses

\begin{tabular}{lll}
\hline ATC classification & ATC drugs & Defined Daily Dose \\
\hline J01C A04 & Amoxicillin & $1 \mathrm{~g}$ (oral or parenteral) \\
J01M A06 & Norfloxacin & $0.8 \mathrm{~g}$ (oral) \\
J01M A02 & Ciprofloxacin & $1 \mathrm{~g}$ (oral) \\
& & $0.5 \mathrm{~g}$ (parenteral) \\
J01F F01 & Clindamycin & $1.2 \mathrm{~g}$ (oral) \\
& & $1.8 \mathrm{~g}$ (parenteral) \\
J01C A12 & Piperacillin & $14 \mathrm{~g}$ (parenteral) \\
\hline
\end{tabular}

ATC Anatomical Therapeutic Chemical

expression of antibiotic consumption in internationally accepted formats. Of course, the ability to start the process is dependant upon access to administrative data. Fortunately, because in many jurisdictions pharmaceuticals are paid for or administered by government agencies, accurate data concerning expenditures are kept. The focus is often financial but volume data are associated.

While any level of aggregated administrative data can be utilized, systems vary widely in the type of information collected. The most desirable level is the simplest one (eg, number of tablets dispensed to an individual on a single prescription). However, aggregated data at a higher level can also be useful (eg, number of grams dispensed in a country in a year).

\section{DRUG CLASSIFICATION SYSTEMS}

\section{Identifying individual drugs}

Countries and hospitals vary widely in the classification systems used for pharmaceuticals. In Canada a Drug Identification Number (DIN) is assigned by the Therapeutic Products Directorate - the national agency that licenses prescription drugs. This number uniquely identifies the active ingredient, manufacturer, trade name, strength, route of administration and dosage form. This type of classification number is often used in government pharmaceutical claims and can be combined with another classification system to facilitate standardized expressions of utilization data.

\section{Classification of drugs by therapeutic categories}

The most widely used, and most useful, classification system for the expression of drug utilization is the Anatomical Therapeutic Chemical (ATC) classification system. The rest of the present paper focuses on the use of this system.

\section{The ATC classification}

The ATC system was initiated in the 1970s by the Norwegian Medicinal Depot, and is now coordinated by the World Health Organization (WHO) Collaborating Centre for Drug Statistics Methodology, established in Oslo in 1982. The centre revises the ATC codes as necessary and maintains an online database and published index. Drugs are divided into different groups according to the organ or system on which they act and/or their therapeutic and chemical characteristics. Each drug is assigned at least one ATC code, which are classified into groups at five different levels. See Table 1 for an illustration using amoxicillin.

Defined daily dose

To facilitate the ability to compare consumption information across time and geography, a technical unit of measurement was created for use in conjunction with the ATC classification. It is referred to as the Defined Daily Dose (DDD) and assigned to each drug at the $5^{\text {th }}$ level (chemical substance) classification. It is defined by the ATC as the assumed average maintenance dose per day for a drug used for its main indication in adults and is assigned by the WHO Collaborating Centre using established principles (see Resources section of this paper). Different DDDs may be assigned for different drug formulations (ie, parenteral versus oral). See Table 2 for some examples of DDDs for antibiotics.

How does one use the ATC/DDD classification with administrative prescription claims data?

If data are available at an individual claim level and the drug is identified with a unique DIN, it is a fairly straightforward process to apply the ATC classification and convert drug quantity into a number of DDDs.

Consider the following hypothetical example (Figure 1) of the application of ATC/DDD to a single prescription claim from a 59-year-old woman with unique Identification Number 545561 dispensed 14 ciprofloxacin $500 \mathrm{mg}$ tablets from a pharmacy in Greenville in September 1995. In this example ciprofloxacin $500 \mathrm{mg}$ tablets are identified with a unique DIN of 1663.

The number of DDDs is a calculated field obtained by multiplying the quantity field by the DDD conversion factor field. In this example, the strength of one tablet is $500 \mathrm{mg}$ and the ATC/DDD is $1 \mathrm{~g}$ for ciprofloxacin. Each $500 \mathrm{mg}$ tablet is equivalent to 0.5 DDD. Multiplication of the quantity dispensed (14 tablets) by a conversion factor of 0.5 equals a total of 7 DDDs dispensed from this prescription.

Data can then be collated, expressed and evaluated based on any other field in the merged record.

Use of ATC/DDD with hospital pharmacy data

Most hospital pharmacies have the ability to express their drug dispensing information in monthly collations of numbers of drugs dispensed by type of drug. If the ATC system is in use in the hospital the information will be routinely expressed in ATC language. If not, as is usual in Canada, the ATC/DDD system can be applied in a similar fashion to the above out-patient prescription example. Commonly, a unique 


\begin{tabular}{|c|c|c|c|c|c|c|c|c|c|c|c|c|}
\hline DIN & \multicolumn{2}{|c|}{\begin{tabular}{|c|} 
Patient \\
ID Number
\end{tabular}} & \multicolumn{2}{|c|}{ Drug Name } & Form & Strength & \multicolumn{2}{|c|}{ Quantity } & Location & Sex & Age & Month \\
\hline 1663 & \multicolumn{2}{|c|}{545561} & \multicolumn{2}{|c|}{ ciprofloxacin } & Tablet & $500 \mathrm{mg}$ & \multicolumn{2}{|c|}{14} & Greenville & \multicolumn{2}{|r|}{59} & 09/95 \\
\hline \multicolumn{13}{|c|}{+} \\
\hline \multicolumn{13}{|c|}{ ATC/DDD Classification Association File } \\
\hline DIN & $\begin{array}{c}\text { ATC } \\
\text { Level } 1\end{array}$ & \multicolumn{2}{|c|}{$\begin{array}{c}\text { ATC } \\
\text { Level } 2\end{array}$} & $\begin{array}{c}\text { ATC } \\
\text { Level } 3\end{array}$ & $\begin{array}{c}\text { ATC } \\
\text { Level } 4\end{array}$ & \begin{tabular}{c|c} 
ATC \\
Level 5
\end{tabular} & \begin{tabular}{|l|} 
ATC \\
DDD
\end{tabular} & \multicolumn{2}{|c|}{$\begin{array}{c}\text { DDD Conversion } \\
\text { Factor }\end{array}$} & & & \\
\hline 1663 & $\mathrm{~J}$ & \multicolumn{2}{|c|}{01} & \begin{tabular}{l|l}
$\mathrm{M}$ & \\
\end{tabular} & $\mathrm{A}$ & \begin{tabular}{l|}
02 \\
\end{tabular} & \begin{tabular}{|l|l|}
1.0 \\
\end{tabular} & \multicolumn{2}{|c|}{0.5} & & & \\
\hline \multicolumn{13}{|c|}{$\begin{array}{l}\text { This is then merged with the claim information linked by DIN. } \\
\text { Merged Record }\end{array}$} \\
\hline DIN & \multicolumn{2}{|c|}{$\begin{array}{c}\text { Patient } \\
\text { ID Number }\end{array}$} & \multicolumn{2}{|c|}{ Drug Name } & Form & Strength & \multicolumn{2}{|c|}{ Quantity } & Location & Sex & Age & Month \\
\hline 1663 & \multicolumn{2}{|c|}{\begin{tabular}{|l|l|l|l}
545561 & \\
\end{tabular}} & \multicolumn{2}{|c|}{ ciprofloxacin } & Tablet & $500 \mathrm{mg}$ & \multicolumn{2}{|l|}{14} & \multirow{2}{*}{\multicolumn{2}{|c|}{$\begin{array}{l}\text { Greenville } \\
\text { SDD Conversion } \\
\text { Factor }\end{array}$}} & 59 & 09/95 \\
\hline DIN & $\begin{array}{c}\text { ATC } \\
\text { Level } 1\end{array}$ & $\begin{array}{r}A \\
\text { Lev }\end{array}$ & $\begin{array}{l}\mathrm{TC} \\
\mathrm{el} 2\end{array}$ & $\begin{array}{c}\text { ATC } \\
\text { Level } 3\end{array}$ & $\begin{array}{c}\text { ATC } \\
\text { Level } 4\end{array}$ & $\begin{array}{c}\text { ATC } \\
\text { Level } 5\end{array}$ & $\begin{array}{l}\text { ATC } \\
\text { DDD }\end{array}$ & & & & DDDs & \\
\hline 1663 & $\mathrm{~J}$ & & 1 & $\mathrm{M}$ & $A$ & 02 & 1.0 & & 0.5 & & 7 & \\
\hline
\end{tabular}

Figure 1) Process of merging typical outpatient pharmacy dispensing data with Anatomical Therapeutic Chemical/Defined Daily Dose (ATC/DDD)

DIN or alphanumeric mnemonic is assigned by the hospital or the manufacturer of the pharmacy operating system that identifies drug, strength and form. The creation of an association file that links the DIN or mnemonic with the ATC/DDD code allows the merging of hospital pharmacy information with ATC/DDD classification.

Consider this example of a report of antibiotics dispensed to hypothetical surgical ward 4West in the month of January 2003 (Figure 2). In this case, the drug description field identifies the drug, the strength and the form.

The number of DDDs is calculated by multiplying the units dispensed field with the DDD conversion factor field. In this case, 300 Cefazolin $1 \mathrm{~g}$ vials are converted to 100 DDDs. Now the information can be expressed in DDDs by the ATC classification.

\section{Expressing consumption information}

Because the ATC/DDD system is continuously being modified, it is essential that the version (year) of ATC classification in use is clearly identified. By convention, the most recent classification is usually used. However, one must be aware of changes in the classification or DDD assignment when comparing with historic information $(13,14)$. All expressions of consumption information in this paper utilize the 2002 version of the ATC/DDD classification.

\section{Rates}

Most commonly, drug consumption is expressed as a rate. Of course, to express a rate, a denominator and time unit must be defined. Common units for antibiotic consumption include DDD per 1000 inhabitant-days for out-patient data and DDD per 100 bed-days in hospitals.

For expressions of antibiotic consumption at the level of a country, province or large region, census population estimates are appropriate. Statistics Canada is a readily available source. Consider the following example from British Columbia (BC). $\mathrm{BC}$ PharmaNet is a government program administered through the BC College of Pharmacists that receives and collates information from all pharmacies in the province. They provided information to the BC Centre for Diseases Control, who applied ATC/DDD in a fashion analogous to the example given in the section on claims information.

Calculation of yearly rates

Here is an example showing the calculation of yearly rates:

Total amount of antibiotics in J01 category dispensed in 1996:

$$
\text { 26,916,839 DDD }
$$

Population (from Census): 3,959,698

$$
\begin{aligned}
& \frac{26916839 \mathrm{DDD}}{3,959,698}=6.80 \mathrm{DDD} / \text { inhabitant-year } \\
& \frac{6.80 \times 1000}{365}=18.63 \mathrm{DDD} / 1000 \text { inhabitant-days }
\end{aligned}
$$

The data (ATC 2000) from British Columbia from 1997 to 2000 is graphically represented in Figure 3.

Consumption levels were quite stable at a rate of approximately 18 DDD per 1000 inhabitant-days during these four 
Monthly Report of Antibiotic Use

Ward 4West Surgery January 2003

\begin{tabular}{|l|l|c|}
\hline $\begin{array}{l}\text { Mnemonic } \\
\text { (Identifier) }\end{array}$ & Drug Description & Units Dispensed \\
\hline CEFA1I & Cefazolin 1 gram vial & 300 \\
\hline CEFU750I & Cefuroxime 750 mg vial & 128 \\
\hline CIPRO500T & Ciprofloxacin $500 \mathrm{mg}$ tablet & 96 \\
\hline
\end{tabular}

$+$

A file associating mnemonic (identifier) to ATC / DDD is created:

\begin{tabular}{|l|c|c|c|c|c|c|c|}
\hline Mnemonic & $\begin{array}{c}\text { ATC } \\
\text { Level 1 }\end{array}$ & $\begin{array}{c}\text { ATC } \\
\text { Level 2 }\end{array}$ & $\begin{array}{c}\text { ATC } \\
\text { Level 3 }\end{array}$ & $\begin{array}{c}\text { ATC } \\
\text { Level 4 }\end{array}$ & $\begin{array}{c}\text { ATC } \\
\text { Level 5 }\end{array}$ & $\begin{array}{c}\text { ATC } \\
\text { DDD }\end{array}$ & $\begin{array}{c}\text { DDD Conversion } \\
\text { Factor }\end{array}$ \\
\hline CEFA1I & $\mathrm{J}$ & 01 & $\mathrm{D}$ & $\mathrm{A}$ & 04 & 3.0 & 0.333 \\
\hline CEFU750I & $\mathrm{J}$ & 01 & $\mathrm{D}$ & $\mathrm{A}$ & 06 & 3.0 & 0.25 \\
\hline CIPRO500T & $\mathrm{J}$ & 01 & $\mathrm{M}$ & $\mathrm{A}$ & 02 & 1.0 & 0.5 \\
\hline
\end{tabular}

This is then merged with the monthly report linked by Mnemonic.

\begin{tabular}{|c|c|c|c|c|c|c|c|c|c|}
\hline $\begin{array}{l}\text { Mnemonic } \\
\text { (Identifier) }\end{array}$ & \multicolumn{4}{|c|}{ Drug Description } & \multicolumn{3}{|c|}{ Units Dispensed } & & \\
\hline CEFA1I & \multicolumn{4}{|c|}{ Cefazolin 1 gram vial } & \multicolumn{3}{|c|}{300} & & \\
\hline CEFU750I & \multicolumn{4}{|c|}{ Cefuroxime $750 \mathrm{mg}$ vial } & \multicolumn{3}{|c|}{128} & & \\
\hline CIPRO500T & \multicolumn{4}{|c|}{ Ciprofloxacin $500 \mathrm{mg}$ tablet } & \multicolumn{3}{|c|}{96} & & \\
\hline Mnemonic & $\begin{array}{l}\text { ATC } \\
\text { Level } 1\end{array}$ & $\begin{array}{c}\text { ATC } \\
\text { Level } 2\end{array}$ & $\begin{array}{c}\text { ATC } \\
\text { Level } 3\end{array}$ & $\begin{array}{l}\text { ATC } \\
\text { Level }\end{array}$ & & $\begin{array}{l}\text { ATC } \\
\text { eevel } 5\end{array}$ & \begin{tabular}{|l|} 
ATC \\
DDD
\end{tabular} & $\begin{array}{c}\text { DDD Conversion } \\
\text { Factor }\end{array}$ & DDDs \\
\hline CEFA1I & $\mathrm{J}$ & 01 & $\mathrm{D}$ & $A$ & & 04 & 3.0 & 0.333 & 100 \\
\hline CEFU750I & J & 01 & $\mathrm{D}$ & A & & 06 & 3.0 & 0.25 & 32 \\
\hline CIPRO500T & $\mathrm{J}$ & 01 & $\mathrm{M}$ & A & & 02 & 1.0 & 0.5 & 48 \\
\hline
\end{tabular}

Figure 2) Process of merging typical monthly hospital pharmacy data with Anatomical Therapeutic Chemical/Defined Daily Dose (ATC/DDD)

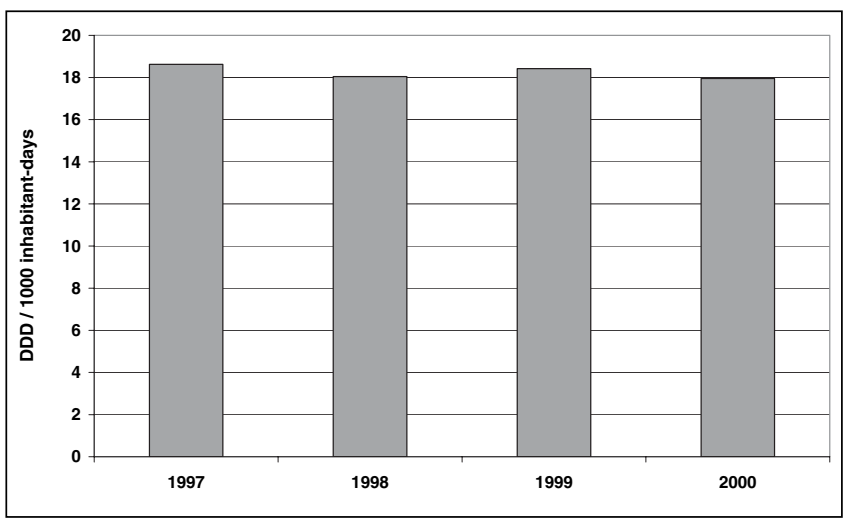

Figure 3) J01 Antibiotic consumption in ambulatory care patients in British Columbia, 1997 to 2000. DDD Defined Daily Dose

years. Comparing these rates with those of Denmark, published in the 2002 Danish Integrated Antimicrobial Resistance Monitoring and Research Programme report (15), gives some context (Figure 4).

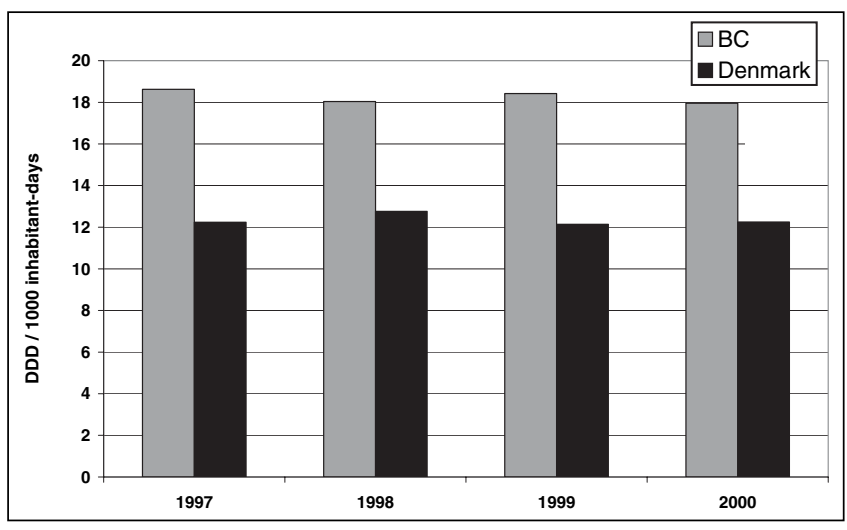

Figure 4) J01 Antibiotic consumption in ambulatory care patients in British Columbia (BC) and Denmark, 1997 to 2000. DDD Defined Daily Dose

The consumption in Denmark was also stable, but at a much lower level, approximately 12 DDD per 1000 inhabitant-days. In ambulatory care, the people of BC consumed about $50 \%$ more antibiotics than did the people of Denmark. 


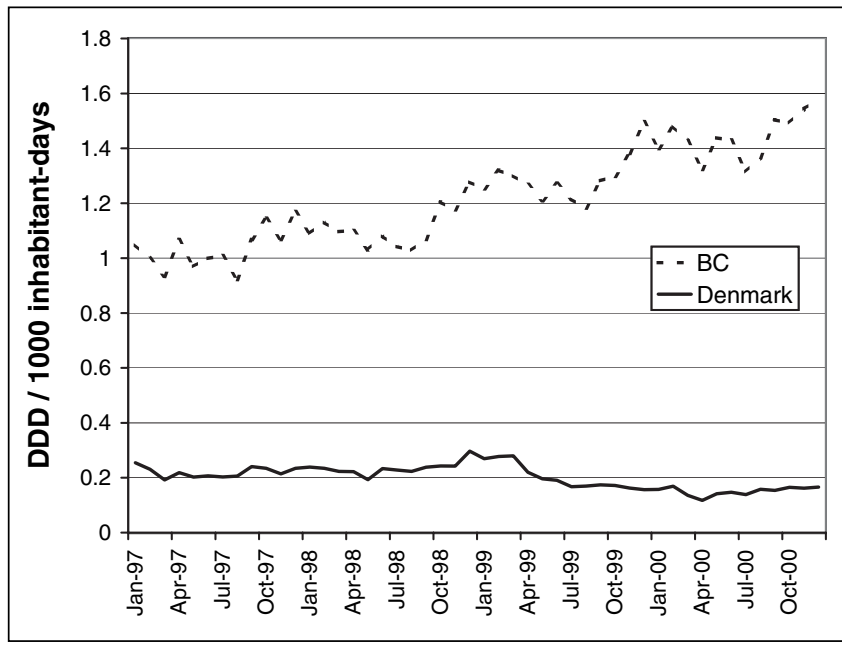

Figure 5) Comparison of rates of consumption of Class J01MA Fluoroquinolones in British Columbia (BC) and Denmark expressed monthly from 1997 to 2000. DDD Defined Daily Dose

A closer look at a specific class of antibiotic reveals further differences. A comparison of rates of consumption of Class J01MA - Fluoroquinolones in BC and Denmark, expressed monthly from 1997 to 2000 is shown in Figure 5. These Danish data were obtained from the Danish Medicines Agency by one of the authors (DM).

Fluoroquinolones were consumed at a much higher rate in British Columbia than in Denmark during this time period and the rate increased in British Columbia while it decreased in Denmark. These differences are easier to see if two different Y-axis scales are employed (Figure 6).

The reduction in consumption in Denmark immediately followed removal of subsidization for fluoroquinolones by the Danish drug plan (16).

Expressing consumption in hospitals

The usual divisions within a hospital are wards (physical divisions) or services (patient group divisions). If information is available divided by service (eg, General Surgery Service, Orthopedic Service), it is preferable to physical ward divisions, which often care for patients from several services ('off-service' patients). The usual volume denominator for hospital statistics is patient-day (often referred to as bed-day). By convention, the discharge day for each patient is not counted to avoid the inflation of the denominator by partial days (admission day and discharge day) being counted as full days.

Consider this example of consumption of category J01 (Antibacterials for systemic use) on the General Surgery Service in the Health Sciences Centre in St John's, Newfoundland from January 1999 to August 2003 in monthly measurements (Figure 7).

The average use was approximately $80 \mathrm{DDD}$ per 100 bed-days in the first two years with considerable month-to-month variation. A 12 -month moving average helps to smooth variation and display an upward increase in the last year of the evaluation period to approximately 90 DDD per 100 bed-days.

Comparisons between similar services in different institutions may yield useful information. Consider this comparison of consumption of ciprofloxacin in the Urology Service of the Healthcare Corporation of St John's with the Urology Service

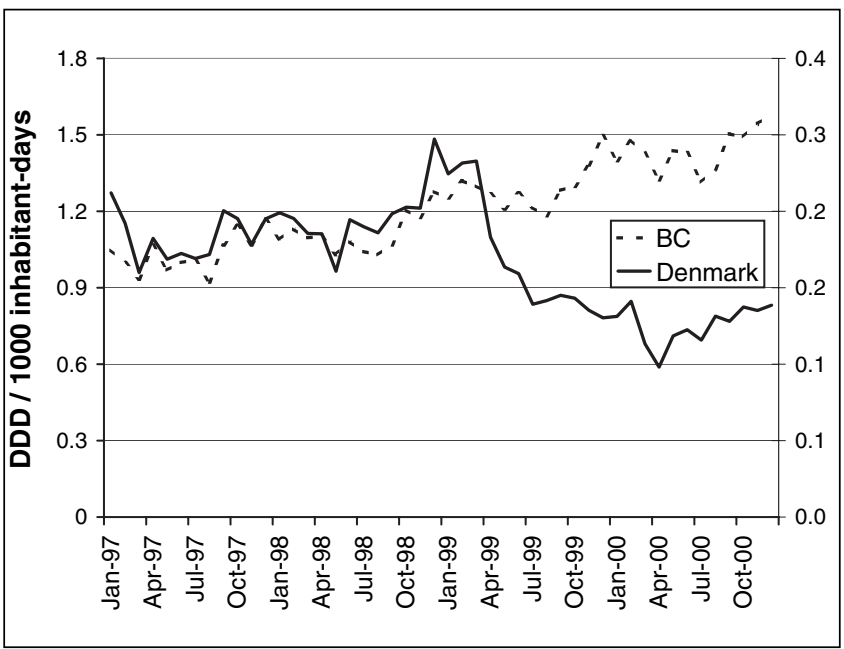

Figure 6) Comparison of rates of consumption of class J01MA fluoroquinolones in British Columbia (BC) and Denmark with different Y-axes. BC is on the left, Denmark is on the right. DDD Defined Daily Dose

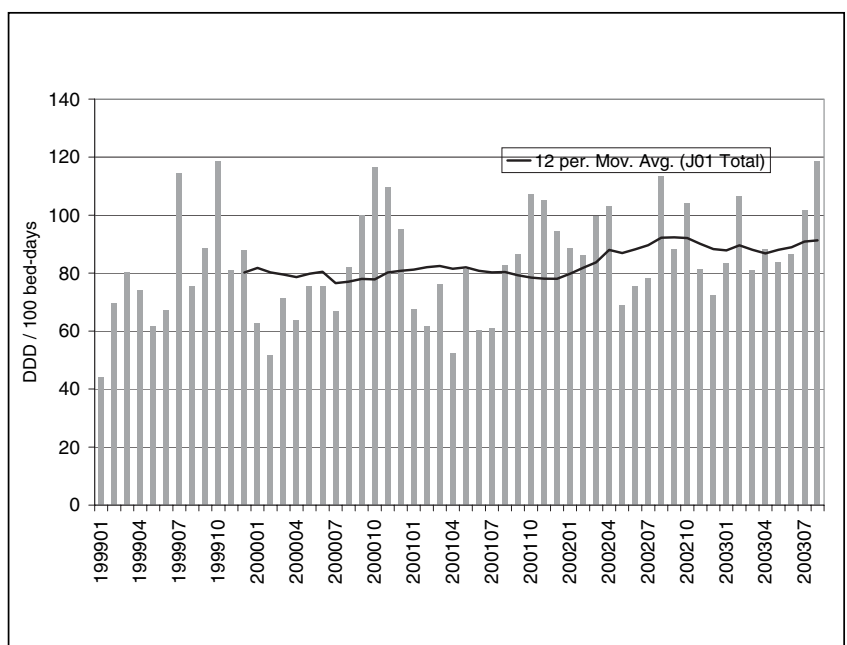

Figure 7) J01 antibiotic use in the Health Sciences Centre's surgery service from January 1999 to August 2003 in monthly measurements. DDD Defined Daily Dose; Mov Avg Moving average

of the Calgary Health Region from April 1999 to October 2002 in monthly data points (Figure 8).

The consumption rate of ciprofloxacin was much higher in St John's than in Calgary during this period; the rate of increase was also greater in St John's. An even closer look demonstrates that the differences were even more pronounced when the intravenous (IV) form of ciprofloxacin is examined in isolation (Figure 9).

There were very large month-to-month variations in St John's, with large increases in the past 18 months. This was not the case in Calgary.

\section{Uses for antibiotic consumption information}

Routine measurement and display of consumption information to prescribers and policy-makers are a first step in increasing the awareness and importance of careful antibiotic use. It is then possible to attempt to define levels of optimal use. 


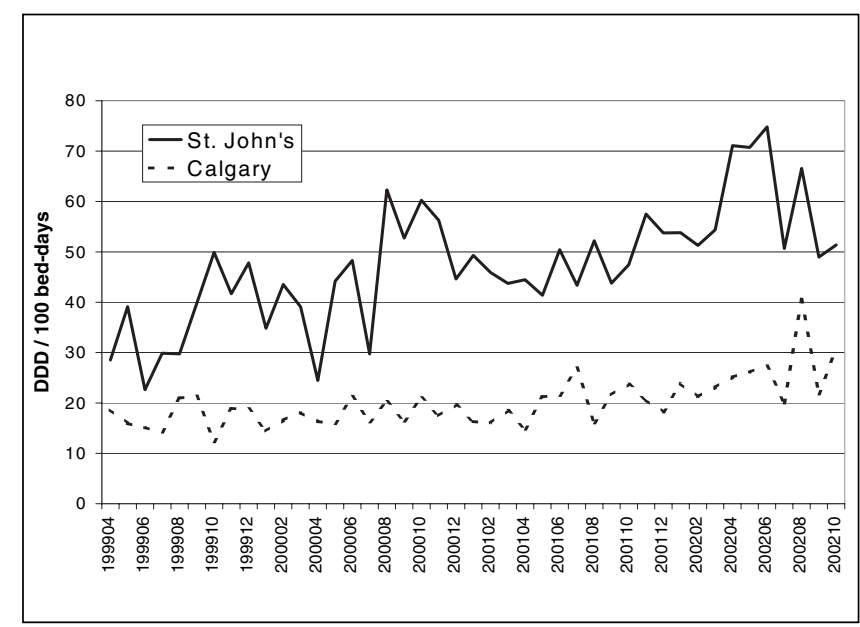

Figure 8) Comparison of consumption of ciprofloxacin (J01MA02) in the Urology Service of the Healthcare Corporation of St John's with the Urology Service of the Calgary Health Region from April 1999 to October 2002 in monthly data points. DDD Defined Daily Dose

Comparative information can help to define those levels by evaluating individual consumption and proportions in the context of recognized leaders in the area. Conformity to local practice guidelines can be evaluated, and expected levels of consumption can be estimated by defining the incidence of disease requiring antimicrobial therapy. Feedback to prescribers is one potential form of intervention.

\section{Provincial pharmacare plans}

Consider the circumstance of pharmacy plan policy-makers in the province of BC. Examples of important and reasonable questions generated by analysis of consumption data are:

1. Is the overall level of consumption of antibiotics better in Denmark or in BC?

a. What measures of health might help to answer this question?

b. What are the effects on antibiotic resistance?

2. Is the level of antibiotic consumption in BC justifiable by rates of bacterial infections?

3. Is it desirable to have increasing rates of consumption of fluoroquinolones?

a. What are the health advantages?

i. In the short term?

ii. In the long term?

b. What are the costs?

i. In the short term?

ii. In the long term?

4. What policy tools are available to influence consumption?

These types of questions could and should be posed by all pharmacy plan decision-makers when evaluating plan policies as they pertain to existing antibiotics but, in particular, to new antibiotics. Potential changes to population antibiotic consumption should be a consideration in all formulary decisions.

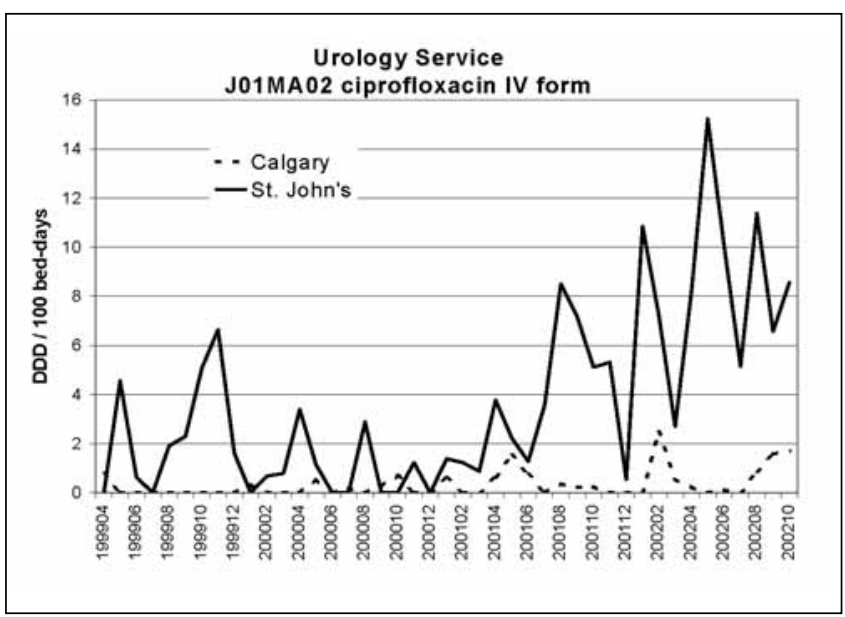

Figure 9) Comparison of consumption of the intravenous (IV) form of ciprofloxacin (J01MA02) in the Urology Service of the Healthcare Corporation of St John's with the Urology Service of the Calgary Health Region from April 1999 to October 2002 in monthly data points. DDD Defined Daily Dose

\section{Hospitals}

In the case of use of the Surgery Service in St John's, a rational question might be, "What explains the increase in antibiotic consumption in the past year?" The ability to ask this complex question serves to focus attention on the issue at the level of service administrators and prescribers. While there are many potential explanations, engaging the decision-makers in the process is essential if attention is to be focused on optimizing antibiotic use.

The specific example of the use of ciprofloxacin, in particular IV ciprofloxacin on the Urology Service in St John's in comparison wtih Calgary, prompts other questions:

1. Are the patients comparable on these Services?

a. How can they be characterized?
i. Age/Sex
ii. Procedures
iii. Diagnoses
iv. Length of Stay

2. Are the rates of infection different on these two Services?

3. Are the bacterial pathogens different?
a. Identity
b. Susceptibility

4. What explains the increase in the IV form of ciprofloxacin use, particularly in St John's?

a. New medical information?

b. Guidelines?

c. Change in patient population (eg, higher proportion unable to eat?)

By answering these questions, it will be possible to define means of comparing these two services that are understandable and meaningful to both. It is possible that this will engender discourse that will help to define optimal antibiotic use in both Urology services. 


\section{SUMMARY}

It is our hope that this document stimulates further interest in measurement and display of population antibiotic consumption. All persons responsible for policy decisions regarding licensing, reimbursement, prescribing guidelines, formulary controls or any other structure pertaining to antimicrobial use should be conversant with the concepts of population antibiotic consumption. Prescribers should be made aware of their own prescribing practices in the context of recognized leaders. The sooner we are able to accurately measure and compare our antibiotic prescribing and consuming behaviour, the sooner we will be able to have reasoned, practical approaches to improvement.

\section{RESOURCES}

The WHO Collaborating Centre for Drug Statistics Methodology has an excellent website at <www.whocc.no/atcddd/>. A free, searchable database of ATC/DDD codes is available on this site, and other excellent resources are for sale, including guidelines for ATC classification and DDD assignment.

The European Union has identified the measurement of antibiotic consumption as a high priority item and has established the European Surveillance of Antibiotic Consumption (ESAC) project. It is a DG SANCO (Health and Consumer Protection Directorate General)-funded

\section{REFERENCES}

1. Mainous AG, Hueston WJ, Clark JR. Antibiotics and upper respiratory infection: Do some folks think there is a cure for the common cold. J Fam Pract 1996;42:357-61.

2. Soyka LF, Robinson DS, Lachant N, Monaco J. The misuse of antibiotics for treatment of upper respiratory tract infections in children. Pediatrics 1975;55:552-6.

3. Hutchinson JM, Jelinski S, Hefferton D, Desaulniers G, Parfrey PS. Role of diagnostic labeling in antibiotic prescription. Can Fam Physician 2001;47:1217-24.

4. Guillemot D, Carbon C, Vauzelle Kervroedan F, et al. Inappropriateness and variability of antibiotic prescription among French office-based physicians. J Clin Epidemiol 1998;51:61-8.

5. Gonzales R, Steiner JF, Sande MA. Antibiotic prescribing for adults with colds, upper respiratory tract infections, and bronchitis by ambulatory care physicians. JAMA 1997;278:901-4.

6. Carrie AG, Metge CJ, Zhanel GG. Antibiotic use in a Canadian province, 1995-1998. Ann Pharmacother 2000;34:459-64.

7. Cars O, Molstad S, Melander A. Variation in antibiotic use in the European Union. Lancet 2001;357:1851-3.

8. Birkett DJ, Mitchell AS, Godeck A, Grigson T, Cully R, Lee C. Profiles of antibacterial drug use in Australia and trends from 1987 to 1989. A report from the Drug Utilization Subcommittee of the Pharmaceutical Benefits Advisory Committee. Med J Aust 1991;155:410-5.

9. Col NF, O'Connor W. Estimating worldwide current antibiotic usage: Report of task force 1. Rev Infect Dis 1987;9(Suppl 3):S232-42.

10. Craig WA, Uman SJ, Shaw WR, Ramgopal V, Eagan LL, Leopold ET. Hospital use of antimicrobial drugs. Survey at 19 hospitals and results of antimicrobial control program. Ann Intern Med 1978;89:793-5. monitoring programme, which collects standardized, harmonized and comparable data on antibiotic consumption. The goal of ESAC is to document variations in antibiotic consumption and translate them into quality indicators for public health monitoring over time and place in order to target interventions and to assess the effectiveness of prevention programmes. Excellent information about the project and antibiotic measurement in general is available on the ESAC website at <www.esac.ua.ac.be>. It also serves as a source for comparative consumption statistics.

An excellent tool for the application of ATC/DDD, the Antibiotic Consumption Calculator created by Dominique L Monnet of the Statens Serum Institute in Copenhagen, is available for free download on the home page of the European Society of Clinical Microbiology and Infectious Diseases Study Group on Antibiotic Policies (ESGAP) at $<$ www.escmid.org/sites/science/studygroups/ index.asp> (click 'ESGAP', then 'News \& Activities').

Dr Ingrid Sketris of Dalhousie University has published a superb manual entitled 'A Canadian Guide for Drug Utilization Studies Using Administrative Claims Data: Focus on the WHO ATC System and Defined Daily Dose' (17). It was developed as part of a Health Transitions Fund Project and gives excellent practical advice to those interested in population drug statistic methodology.

11. Finkel MJ. Magnitude of antibiotic use. Ann Intern Med 1978;89:791-2.

12. Janknegt R, Oude Lashof A, Gould IM, van der Meer JW. Antibiotic use in Dutch hospitals 1991-1996. J Antimicrob Chemother 2000;45:251-6.

13. Rønning M, Blix HS, Harbo BT, Strom H. Different versions of the anatomical therapeutic chemical classification system and the defined daily dose - Are drug utilisation data comparable? Eur J Clin Pharmacol 2000;56:723-7.

14. Rønning M, Blix HS, Strom H, Skovlund E, Andersen M, Stichele RV. Problems in collecting comparable national drug use data in Europe: The example of antibacterials. Eur J Clin Pharmacol 2003;58:843-9.

15. DANMAP 2002. Use of antimicrobial agents and occurrence of antimicrobial resistance in bacteria from food animals, foods and humans in Denmark. Copenhagen, Denmark: Copenhagen Veterinary Institute, 2002. < http://www.dfvf.dk/Default.asp?ID=9604> (Version current at February 3, 2004).

16. DANMAP 2001. Use of antimicrobial agents and occurence of antimicrobial resistance in bacteria from food animals, foods and humans in Denmark. Copenhagen, Denmark: Copenhagen Veterinary Institute, 2001. <http://www.dfvf.dk/Default.asp?ID=9604> (Version current at February 3, 2004).

17. Sketril IS, Metge C, Blackburn J, et al. A Canadian Guide for Drug Utilization Studies Using Administrative Claims Data: Focus on the WHO ATC System and Defined Daily Dose. Supported by the Health Transition Fund, Health Canada, May 2001. 


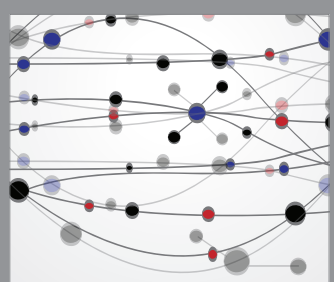

The Scientific World Journal
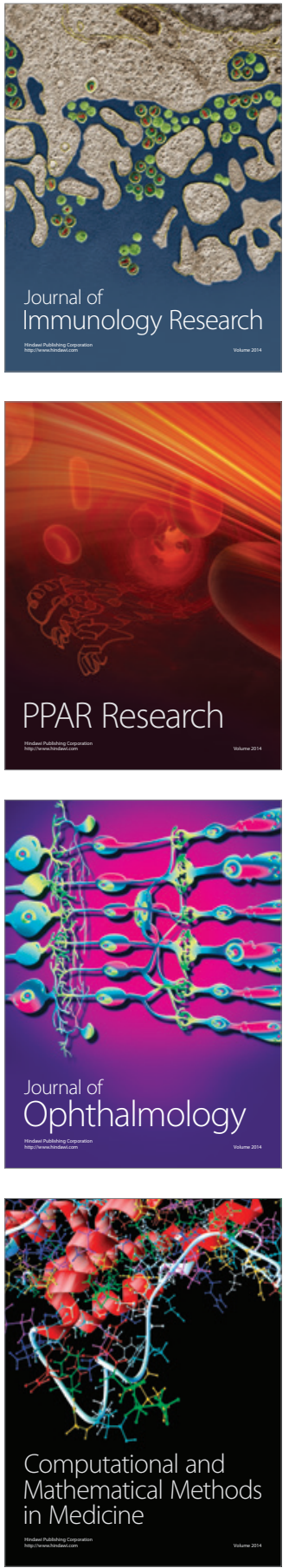

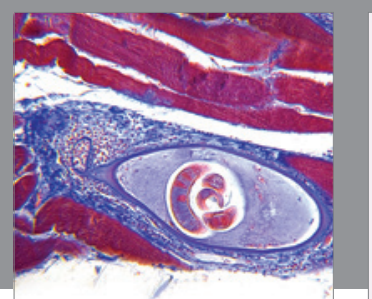

Gastroenterology Research and Practice

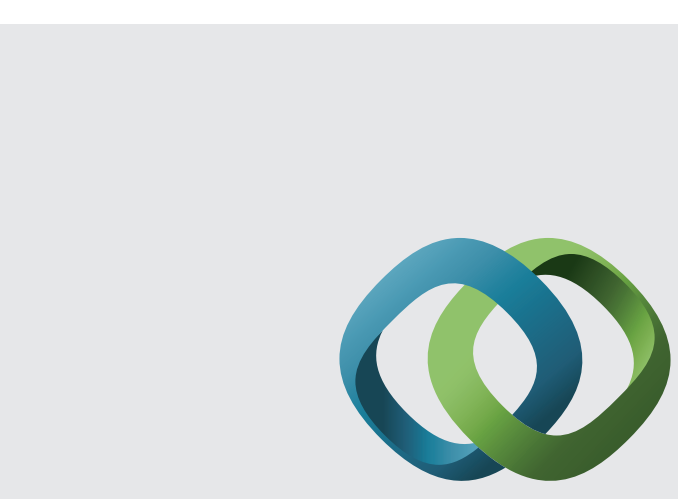

\section{Hindawi}

Submit your manuscripts at

http://www.hindawi.com
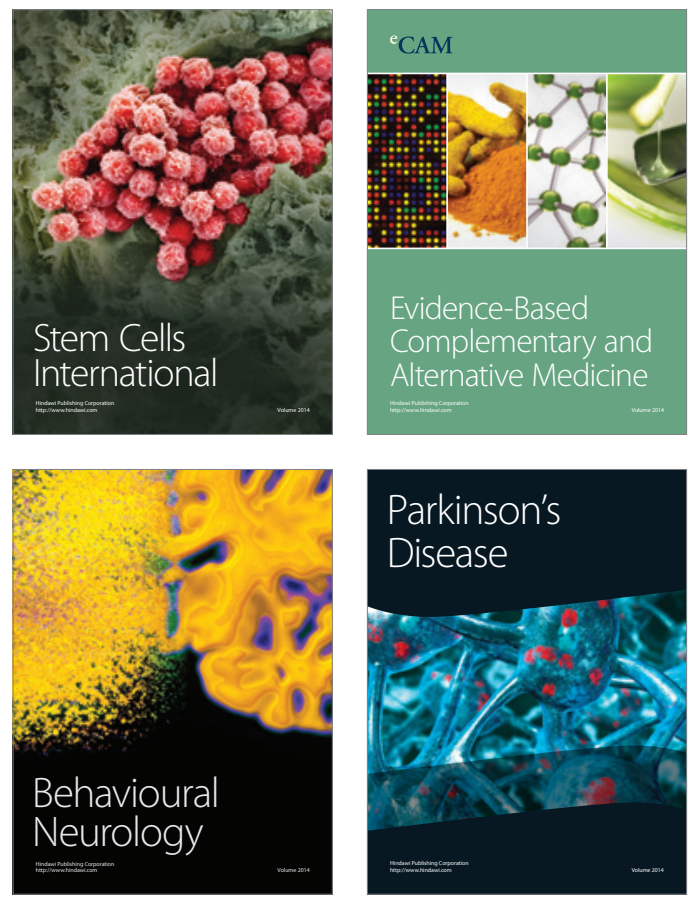
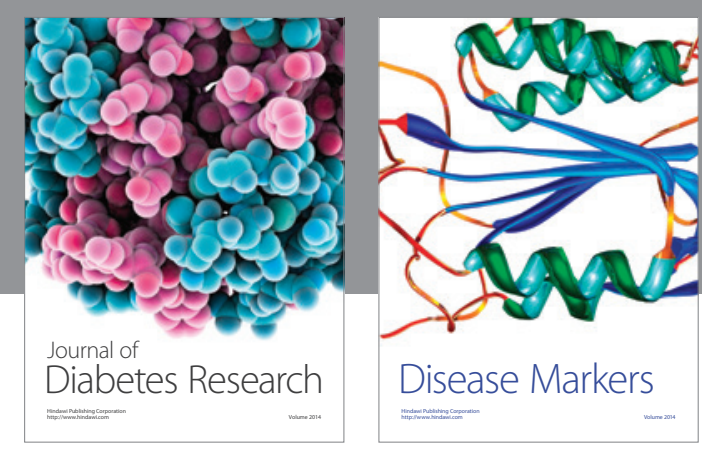

Disease Markers
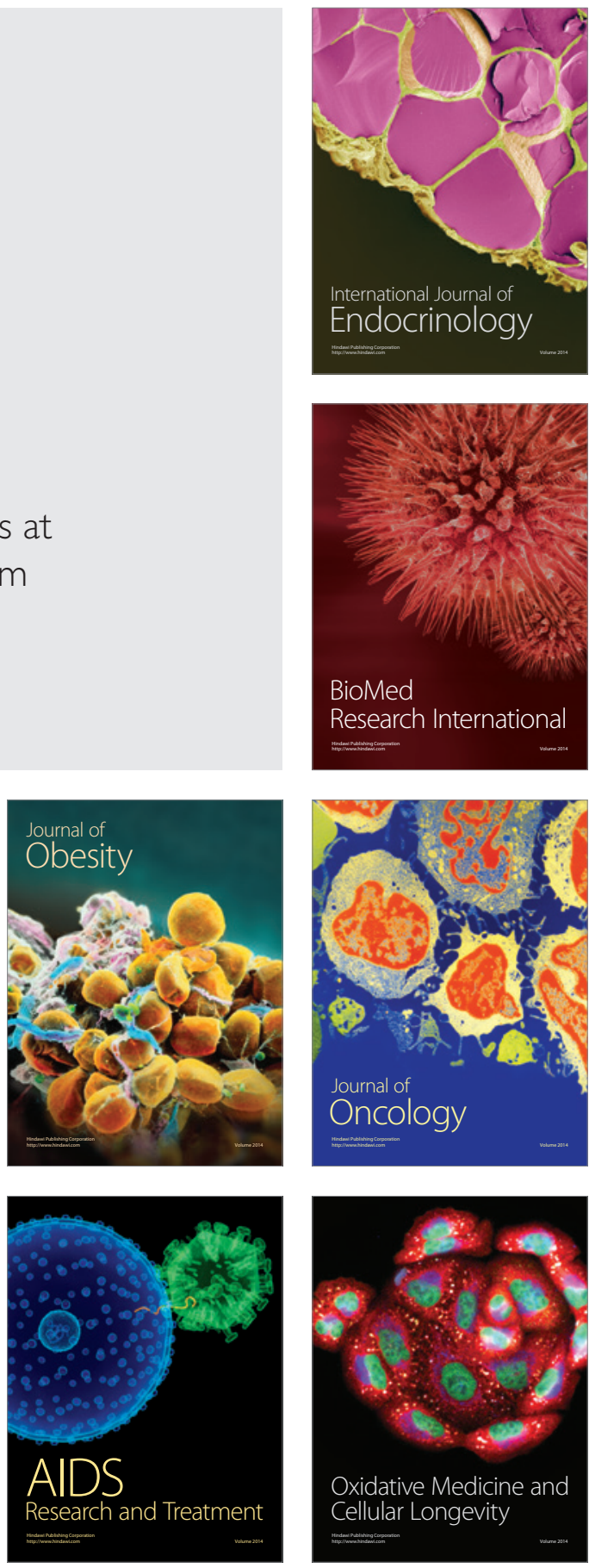